\title{
A Brief Overview of Digital Military Systems Used in the Armies of NATO Member Countries
}

\section{A NATO-tagországok által alkalmazott digitális katonai rendszerek rövid áttekintése}

Today's wars have undergone significant change. These changed military operations have changed the way armies are deployed, including the role and responsibilities of soldiers. New tools are needed to overcome the new challenges. $21^{\text {st }}$ century soldiers need $21^{\text {st }}$ century equipment to perform their duties. A project is present in several NATO (North Atlantic Treaty Organisation) member states army to develop individual equipment systems for dismounted soldiers equipped with modern military equipment, which are in the pilot phase, under introduction or authorised. I present these briefly in my publication.

Keywords: C4I, digital soldier, DSS, NATO, soldier modernisation program

A ma háborúi jelentős változáson mentek át. Ezek a megváltozott katonai müveletek megváltoztatták a hadseregek alkalmazásának módját, ezen belül a katonák szerepét és feladatait. Az új kihívások leküzdéséhez új eszközökre van szükség. A 21. század katonáinak 21. századi felszerelésre van szükségük feladataik végrehajtásához. Több NATO-tagország haderőiben van jelen kísérleti fázisban lévő, bevezetés alatt álló vagy rendszeresitett, modern hadeszközökkel felszerelt gyalogos katonák egyéni eszközrendszereinek fejlesztésével foglalkozó projekt. Ezeket mutatom be röviden a publikációmban.

Kulcsszavak: C4I, digitális katona, DSS, NATO, modernizációs program 


\section{Introduction}

Nowadays, the increasing digitisation of everyday life is common. Army force development is no exception. Armies in different countries are introducing computeraided or controlled systems in an increasing number of areas. But the war is still fought by soldiers against soldiers. Thus, this process also reached the level of each soldier.

However, today's wars have undergone significant change. These changed military operations have changed the way armies are deployed, including the role and responsibilities of soldiers. ${ }^{2}$ Soldiers are playing an increasingly important role in international counter-terrorism, peace support, humanitarian operations, local wars and in effectively resolving crises out of ethnic or religious conflict.

Therefore, soldiers need to be prepared to perform the tasks arising from their new role. Among other things, for dynamic combat activities in urban or built-up areas, for which accurate detection in urban and other areas is of paramount importance. For capturing image and geoinformation data from the explored area. For real-time transmission of the obtained discovery data and information. To detect, mark and destroy the most important goals. Action against terrorist acts. To interfere with enemy electronic devices (communications). ${ }^{3}$

The analysis so far shows that the tasks of the soldiers have undergone a significant change. As a result of the new challenges, it has become a requirement that the soldier be able to perform several different types of tasks with great independence. However, performing such a 'multifunctional' role requires that the soldier be equipped with the most modern equipment. The device systems required to perform the tasks are collectively referred to as dismounted soldier system (DSS). The DSS system can be defined as a combination of elements that support the mission to be performed. It consists of elements that the soldier wears on his/her body or head, that he/she carries in his/her backpack, and that are fitted to his/her weapon system.

Most NATO member countries have a project in the pilot phase, under introduction or authorised to develop DSS in their army. These are made with different design principles in mind, but there are a number of general trends in their development. They evolve into integrated solutions by integrating previously created or upgraded subsystems and components. Integrated DSS systems are usually modular systems with a customised solution for each soldier.

These systems are military improvements, so there is only limited information available. In most cases, we can learn more about the results achieved or a press release on a closed milestone. It can be possibly approached from the financial side from the tenders announced or when the winning tender is announced. Therefore, the improvements presented may be in a more advanced state than described here.

Szabolcs Jobbágy, 'A negyedik generációs hadviselés infokommunikációs aspektusai - fogalmi kitekintő', Hadmérnök 12, no 1 (2017), 212.

Tibor Kőszegvári, 'Hadviselés a 21. században', Hadtudomány 9, no 1 (1999). 


\section{Presentation of the systems of NATO member countries}

In this chapter, I briefly present the individual equipment systems of dismounted soldiers equipped with modern military equipment used in their army in a NATO member country.

\subsection{Albania}

Albania has no known modernised modular military system modernisation project.

\subsection{The United States of America}

\section{Integrated Military Force and Data Development (Nett Warrior)}

Nett Warrior is the successor of Land Warrior. The project aims to 'improve soldiers' situational awareness and communication', the same as the Land Warrior, however, the method is very different. Instead of a self-manufactured defence contractor, COTS (commercial off-the-shelf) technology is used and integrated with existing military hardware. Nett Warrior has shown that existing commercial technologies can be combined quickly and efficiently with military hardware and software to create effective military systems for a soldier. ${ }^{4}$ The development is currently in the team testing phase.

\section{Tactical Air Control Party (TACP)}

The Tactical Air Control Party (TACP) modernisation focus on reducing reliance on voice transmission and replacing analogue equipment with the latest data connection and video streaming technology to meet the needs of today's land and computer battlefield. This is done by targeting three main areas: installed, decommissioned equipment and communication software. ${ }^{5}$

The introduction of the modern dismounted soldier system consisted of the distribution of multiband manpack radios. This was followed by small laptops, followed by pocket laser rangefinders, handheld laser markers and mini thermal binoculars. Later, video receivers and TOC light/heavy computers. TACPs operate as a variety of dismounted field equipment. Some can be connected, such as connecting a laser rangefinder and GPS to provide accurate target coordinates. ${ }^{6}$

The TACP modernisation is moving toward the acquisition of more efficient pieces of dismounted equipment, as efficiency, size and weight affect soldier performance.

Joseph L Rosen and Jason W Walsh, The Nett Warrior System: A Case Study for the Acquisition of Soldier Systems. Naval Postgraduate School, 2011.

'TACP-Modernization', Soldier Systems, s. a.

Adam J Hebert, 'The Ground Warriors of Airpower', Air Force Magazine, 05 September 2005. 
Therefore, small wearable computers are being replaced by TACP computer kits, which consist of an integrated computer, a vest and cable systems. This is the Android tactical assault kit, installed for AFSOC (Air Force Special Operations Command) units, displays moving maps and overlaps the position of friendly forces. ${ }^{7}$ The development is currently in the team testing phase.

\subsection{Belgium}

BEST (Belgian Solder Transformation) has joined the Dutch VOSS program. Primarily in the development of the $\mathrm{C} 4 \mathrm{I}$ system. ${ }^{8}$ There is only a prototype of the system.

\subsection{Bulgaria}

Bulgaria has no known integrated modular military system modernisation project.

\subsection{The Czech Republic}

It develops the soldier's modernisation program as V-21 (Voják 21). According to the concept, the ' $21^{\text {st }}$ Century Soldier' optimises the abilities of soldiers and commanders to make decisions in real time using a system that connects each soldier's individual system with members of their own or cooperating unit. There are two levels of design, a full version and a C4I-free version. Modular design, separate assembly for dismounted soldiers and separate for commander. In terms of hardware, all systems are the same, the differences are in the software. The central computer centre mounted on the chest can be operated using the four buttons mounted on the weapon or a separate grip while keeping a monocular display close to the eye for viewing. The work also included integration into vehicles. They want to be used for rehearsals, for physical control of the teams: temperature, pulse, hydration and dehydration, etc. ${ }^{9}$

There is only a prototype of the system.

\subsection{Denmark - DANES (Danish Army Network Enabled Soldier)}

Following an evaluation of U.S. Land Warrior, French FELIN, U.K. FIST and German IdZ equipment, first efforts to deploy the entire military system through the Danish Army Network Enabled Soldier (DANES) concept have been abandoned with a stepby-step approach to mature technology to support operations in Afghanistan. Priority 
will be given to improving mortality, survival, sustainability, mobility and C4I. Under the auspices of DANES, the Army continued to define the technical and operational requirements for the future Decommissioned Battle Management System (DBMS). In the medium term (five to ten years), the plans call for the purchase and implementation of a DBMS and sensors and monitoring equipment. ${ }^{10}$

There is only a prototype of the system.

\subsection{The United Kingdom - General Soldier Architecture}

The GSA is a platform-specific architecture whose physical implementation is the digital soldier system. The GSA defines the energy and data infrastructure to be implemented by the DSS and the characteristics of the interfaces. The military platform should support a combination of past and future GSA-compliant persons.

The GSA defines an on-the-man architecture, providing a modular approach that allows the architecture to support the installation of different persons required by each member of the fire team, section or team. The U.K. is currently developing an advanced standard, GSA DEF STAN 23-12, which in turn is used to control all equipment used by dismounted soldiers.

This GSA can be applied to a complete set of DSS equipment, from simple to complex implementation. They will be applied to all future British military platforms for capability acquisition and equipment upgrade programs.

The purpose of defining GSA is to minimise physical, operational and cognitive burdens, encourage continuous improvement, and reduce costs. Be compatible with past and future systems. The assembly of the system should be 'plug and play' for the soldiers. Reduce the burden on individual soldiers in terms of weight, cognitively and thermally. Improve operational efficiency.

Further aspect of development is to ensure continuous improvement. Support the possibility of gradual improvement of systems. Facilitate the integration of technology into existing systems. And cost reduction was also a consideration by providing interfaces that meet publicly available open standards. Use modular components to secure third-party modules. Use as best as possible the chance of COTS. ${ }^{11}$ There is only a prototype of the system.

\subsection{Northern Macedonia}

Northern Macedonia has no known integrated modular military system modernisation project.

'The Concise Global Industry Guide - C41 Systems'. C4I Systems Handbook no 12 (2018), 142.

'MODUK - DEF STAN 23-012, Generic Soldier Architecture (GSA)', Engineering 360, 14 May 2017. 


\subsection{Estonia}

Estonia has no known integrated modular military system modernisation project.

\subsection{France}

FÉLIN (Fantassin à Équipements et Liaisons Intégrés) is the French dismounted soldiers system of the future. FÉLIN combines the modified FAMAS rifle with a number of other electronics, clothing, pouches and body armour. The helmet is an integrated SPECTRA helmet, equipped with real-time positioning and information system and with night vision amplifiers. The Portable Electronic Platform (PEP) is a central part of the FÉLIN system. All electronic equipment of the vest is connected to the PEP. It connects to the RIF (Radio Individuelle FÉLIN) voice and data network, which connects the soldier with another dismounted soldier in the section and the section commander. The commander connects to the SITEL battle management system, which is located in a vehicle. ${ }^{12}$

FÉLIN is supplied by Sagem to the Délégation Générale pour l'Armement (DGA), the French Ministry of Defence Procurement Agency. ${ }^{13}$ The system has already been introduced in the French army.

\subsection{Greece}

The Future Soldier System program of the Greek Armed Forces, in its current state, focuses on the protection of the dismounted soldier on the battlefield. The following protective equipment was renewed within the project:

- Palate Carrier vest

- Additional ballistic plates

- Communication system with earmuffs

- Combat belt

- Binoculars (depending on the gain)

- Ballistic glasses

- Backpacks

- Hi-Cut helmets ${ }^{14}$

There is only a prototype of the system.

'Felin Infantry Combat Suite', Defense Update, 27 June 2007.

'FELIN (Fantassin à Équipements et Liaisons Intégrés) - Future Infantry Soldier System', Army Technology, s. a.

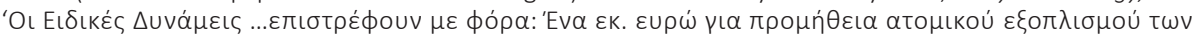

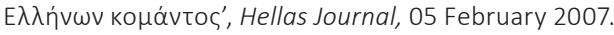




\subsection{The Netherlands}

The Dutch soldier modernisation program is called VOSS (Verbeterd Operationeel Soldaat Systeem). The system consists of the following elements:

- Smart vest

- Communication system

- C2 system

The smart vest is based on Elbit Systems' DOMINATOR system, which are lightweight, modular and scalable and will connect to existing systems. The mobile communication system was designed for soldiers. With the touch screen, soldiers can see each other's locations, access and send information. Thanks to the radio with GPS receiver, soldiers can communicate directly with command and other units. ${ }^{15}$ There is only a prototype of the system.

\subsection{Croatia}

Croatia has no known integrated modular military system modernisation project.

\subsection{Iceland}

Iceland has no known integrated modular military system modernisation project.

\subsection{Canada - Integrated Soldier System (ISS)}

The ISS improves the situational awareness of individual soldiers, provides them with up-to-date and secure communication and navigation capabilities. The ISS can be integrated into the Canadian army land command support system. ${ }^{16}$

The ISS is based on the Saab 9Land system. The 9Land Soldier system solution provides information support to individual soldiers and section commanders in combat situations. The Government of Canada has commissioned Rheinmetall Canada to develop the Integrated Soldier System. Rheinmetall Canada uses Saab AB's display and power system and Invisio earphone technology. But voice communication is the primary capability, the computer device is only additional equipment. ${ }^{17}$

In addition to the ISS, Canada is continuing a project to develop the former Advanced Soldier Adaptive Power (ASAP) concept. The ASAP concept is a wearable tactical vest that forms the spine of power supply and data exchange between equipment and power sources carried by a soldier. ${ }^{18}$

\footnotetext{
'Verbeterd Operationeel Soldaat Systeem', Militaire-Uitrusting, s. a.

'Integrated soldier system project', Government of Canada, s. a.

'9Land Battle Management System', Saab, s. a.

'Canada turns need into reality', Soldier Modernisation, s. a.
} 
The ISS is in the team testing phase, ASAP only exists as a prototype.

\subsection{Poland - Project TYTAN}

ISW Tytan (in Polish: Indywidualny System Walki Tytan [Individual Warfare System Titan]) is the Polish Future Soldier military project.

Within the framework of the program, the aim is to develop new weapons, combat helmets and uniforms, ballistic protection, tactical equipment, optics, communication systems, the C4I system and the provision of their energy supply. ${ }^{19}$ The development is currently in the team testing phase.

\subsection{Latvia}

Latvia has no known integrated modular military system modernisation project.

\subsection{Lithuania}

Lithuania has no known integrated modular military system modernisation project.

\subsection{Luxembourg}

COMPASS (Cooperative Modernization Program of the Army for the Soldier System) has joined the Dutch VOSS program. Primarily in the development of the C4I system. The basic element of the system is the smart vest. Includes all C4I equipment, such as Elbit Systems PNR-100 software-defined radio, battery, cabling and smartphone. ${ }^{20}$ There is only a prototype of the system.

\subsection{Hungary}

The Hungarian Armed Forces announced the Digital Soldier Program as part of the Zrínyi 2026 Defence and Force Development Program. Within the framework of the program, new military clothing, new handgun and a new helmet were developed and introduced. They are now working to turn the equipment into a system and digitise it. This requires the development and integration of extended spectrum 
PÉTER TÖRÖK: A Brief Overview of Digital Military Systems Used in the Armies...

reconnaissance, information transmission, information display, health status reporting and force tracking subsystems. ${ }^{21}$

The development is currently in the team testing phase.

\subsection{Montenegro}

Montenegro has no known integrated modular military system modernisation project.

\subsection{Germany}

The IdZ (Inferterter a Zukunft Erweitere System) soldier system is a modularly dismounted soldier system, comprising the following subsystems:

- Clothing, protective equipment and personal load bearing equipment

- Weapons, displays and sensors

- Command, control, communication, computers and information (C4I)

The IdZ-BS (Infanterist der Zukunft - Basic System) was developed by EADS (European Aeronautic Defence and Space) until 2014, and by Airbus electronics since $2014 .^{22}$ In the system, the digital moving map display system shows the soldier's own position, the position of his/her comrades, the position of minefields and other danger zones, the target and target direction, the target coordinates and the position of the enemy. Current position data is obtained from a higher level. Digital voice and data radio communication provides immediate commands and reconnaissance data to the soldier. IdZ is available in three different configurations:

- Squad Leader

- Standard Soldier

- Rifleman ${ }^{23}$

The system has already been introduced in the German army.

\subsection{Norway}

The modernisation program for the Norwegian soldier is the Norwegian Modular Arctic Network Soldier (NORMANS) program. Modularity was the main consideration in its design, and after the first tests they focused on increasing combat efficiency and safety. There are two configurations: NORMANS Light and NORMANS Advanced. NORMANS Light is a simple navigation and communication unit that increases the

21 Szűcs László, '„A Digitális Katona Program a Magyar Honvédség teljes gondolkodásmódját meg fogja változtatni”. Beszélgetés dr. Böröndi Gábor altábornaggyal, a Magyar Honvédség parancsnokának helyettesével', Honvédelem.hu, 15 February 2021.

22 'IdZ (Infanterist der Zukunft) Future Soldier System', Army Technology, s. a.

23 'IdZ-ES Ready for Delivery', Soldier Modernisation, s. a. 
soldier's situational awareness. The unit has a graphical display that gives the soldier the relative position of team members, observations, waypoints and predefined messages. NORMANS Advanced is a command system. It provides an up-to-date picture of situational awareness, increases control and strengthens command. The design focuses on mobility and ease of use. NORMANS Advanced includes an interactive planning tool where waypoints, areas, routes and other critical information are written on a map and distributed to soldiers. The system facilitates fast mission planning, easy-to-communicate orders, fast and accurate reporting and situation recognition.

The system has already been introduced in the Norwegian army. ${ }^{24}$

\subsection{Italy - Soldato Futuro}

The development of the Soldato Futuro system was initiated by the Italian Ministry of Defence. The system consists of seven main modules:

- Clothing and protection

- Helmet

- C2 system

- Communication

- Target capture

- Handgun

- Armoured fighting vehicle ${ }^{25}$

The combined combat vest and universal support module include cables to integrate the electrical components worn and carried by the Soldato Futuro. The body armour provides puncture protection and protection against $9 \mathrm{~mm}$ projectiles. As an additional protection, boron carbide plates can be fitted to the body armour to also provide protection against $7.62 \mathrm{~mm}$ armour-piercing projectiles. A new material with a disturbing pattern has been designed for the temperate and desert environment of the uniform.

The helmet has a shatter and bulletproof, as well as a laser safety glasses. It also includes a helmet-mounted display (HMD) that displays information about the low-level TV camera mounted on the back of the helmet. It also includes the Night Mobility Subsystem (NIMOS).

The C2 system uses a touch screen to send and receive information in both text and graphic/picture messages, and displays tactical situations, navigation data, Global Positioning System data on digital maps. The touch screen is connected to a pocket-sized computer that uses a standard man machine interface (MMI). ${ }^{26}$ The system has already been introduced in the Italian army.

'Ways and Means', Soldier Modernisation, s. a.

'Soldato Futuro Future Soldier System', Army Technology, s. a.

'Soldato Futuro: 'Precursor' Systems Under Trial', Soldier Modernisation, s. a. 


\subsection{Portugal}

Portugal has no known integrated modular military system modernisation project.

\subsection{Romania - RIFS (Romanian Individual Fighting System)}

A key consideration in setting the requirements was to ensure compatibility with the forces of other NATO members. The C4I system uses IP-based communication, so it implements both voice and data transmission. ${ }^{27}$ The development is currently in the team testing phase.

\subsection{Spain - Combatiente Futuro}

The Spanish Army's modernisation program is COMFUT (COMbantiente FUTuro). The system provides a real-time C2 system for each team member. The COMFUT system includes a radio, GPS, helmet-mounted camera, night vision goggles, laptop, helmet and gun. The $\mathrm{C} 2$ system provides situational awareness with blue force tracking information: squad members and target position. ${ }^{28}$ The development is currently in the team testing phase.

\subsection{Slovakia}

The Prokrocily Individualny Bojovy System (PIBS) is the Slovak army's response to the challenges of the $21^{\text {st }}$ century. The development also included the development of C4I capability, armaments, clothing and a ballistic end. The project was halted before its full implementation, but the results of research improvements were incorporated into the Army's modernisation program. The reason for the shutdown is the lack of financial resources. Slovakia has also joined the EAD modernisation program and is trying to adopt solutions successfully implemented or tested elsewhere in its own system. ${ }^{29}$ The system development has been stopped.

\subsection{Slovenia}

The Slovenian Armed Forces integrated modular military system modernisation project is the $21^{\text {st }}$ Century Warrior. The program has been running for over twenty years and is almost complete except for the C4I subsystem. During development, handguns, personal and weapon optics, night vision goggles, C2IS system and communications, 
and uniforms and protective equipment were replaced. ${ }^{30}$ The system has already been introduced in the Slovenian army.

\subsection{Turkey}

The Turkish Armed Forces integrated modular military system modernisation project is Tek Er. ${ }^{31}$

\section{Conclusions}

The presented dismounted soldier systems generally describe the modernisation efforts of NATO member forces. Although DSS developers can make different design decisions, there are a number of general trends in development and priorities. Future military systems will evolve into integrated military system solutions. Most NATO member countries have military system modernisation programs in place, or at least have plans. Some are still in the concept phase, many are testing prototypes, and others have already systematised them.

All of these military systems require continuous improvement and refinement. The general trend in DSS is toward modular systems in which the soldier connects only the equipment he/she intends to use during the mission. This is due in most cases to a reduction in weight load. DSSs are tailored to the specific role of the soldier. Ideally, the architecture of the military system should allow for continuous upgrades from core capabilities to advanced configuration.

For the presented systems, two main system design options are possible, both modular approaches:

1. Several standard DSS configurations have been developed for specific roles.

2. Configuration of the military core system, which can be expanded step by step to a more advanced configuration by connecting and disconnecting the necessary devices (continuous modularity). Most military systems, such as the German, the Italian, the Dutch and the Norwegian military systems, choose the second approach and distinguish between two or three configurations: Basic configuration for each soldier and advanced configurations for the commander. Sometimes a separate DSS is developed for a specific role.

The base system facilitates basic capabilities that always include voice and location information, that is, radio and GPS. The advanced system supports force tracking, usually with a display interface for sending/receiving commands. Another trend related to modular military systems is the rapid technological development of components/devices. When introduced, a high-tech solution may become obsolete in a few years. Ideally, DSS should allow for component-by-component upgrades.

'Slovenia: Warrior of the 21st Century', Soldier Modernisation, s. a.

Overview of Dismounted Soldier Systems (The NATO Science and Technology Organization, 2018). 
In practice, this is often possible by replacing subsystems. Modular military systems support the integration of advanced technologies into military systems. To support ever-evolving technologies, military systems are increasingly evolving into an open platform system.

There is a clear trend in purchasing complete systems from a single supplier (monolithic military system) towards a procurement process in which MoD acts as a system integrator and it is up to the industry to deliver the components. FÉLIN and IdZ are monolithic systems designed with a specific set of components, while the newer Nett Warrior and GSA systems are open platforms where individual components can be connected to the military platform. These open platforms define the communication protocol and relationships so that the industry can use it to design their products.

Open platform interfaces stimulate COTS integration. ${ }^{32}$ All countries are interested in open platform interfaces to encourage COTS integration. Linked to the development trend of the open platform is the direction of custom computing and robust display components towards COTS computing and display solutions such as (robust) smartphones. As a result of the rapid development of lower-performance enhanced-capability smartphones, nations are exploring the possibility of integrating a smartphone into their military system.

What will be the optimal solution no one knows yet, developers are still looking for the ideal path.

\section{References}

Breczko, Bolesław, 'Polski żołnierz przyszłości Tytan znów opóźniony. Najwcześniej w 2021'. WP tech, 24 November 2019. Online: https://tech.wp.pl/polski-zolnierzprzyszlosci-tytan-znow-opozniony-najwczesniej-w-2021-6449545410017409a

'Canada turns need into reality'. Soldier Modernisation, s. a. Online: www.soldiermod. com/summer-08/prog-issp.html

'COMFUT'. Deagel, s. a. Online: www.deagel.com/Cannons\%20\&\%20Gear/COMFUT/ a000014

Eshel, Tamir, 'Benelux Invest \$150 million in Infantry Smart Vests'. Defense Update, 02 July 2015. Online: https://defense-update.com/20150702_smart_vest.html

'FELIN (Fantassin à Équipements et Liaisons Intégrés) - Future Infantry Soldier System'. Army Technology, s. a. Online: www.army-technology.com/projects/felin/

'Felin Infantry Combat Suite'. Defense Update, 27 June 2007. Online: https://defenseupdate.com/20070627_felin.html

Hebert, Adam J, 'The Ground Warriors of Airpower'. Air Force Magazine, 05 September 2005. Online: www.airforcemag.com/article/0905warriors/

'IdZ-ES Ready for Delivery'. Soldier Modernisation, s. a. Online: www.soldiermod. com/volume-8/idz-es.html

32 Imre Négyesi, 'COTS rendszerek alkalmazási lehetőségeinek vizsgálata', Hadtudományi Szemle 4, no 4 (2011), 113. 
'IdZ (Infanterist der Zukunft) Future Soldier System'. Army Technology, s. a. Online: www.army-technology.com/projects/idz/

'Integrated soldier system project'. Government of Canada, s. a. Online: www.canada. ca/en/department-national-defence/services/procurement/integrated-soldiersystem-project.html

Jobbágy, Szabolcs, 'A negyedik generációs hadviselés infokommunikációs aspektusai - fogalmi kitekintő'. Hadmérnök 12, no 1 (2017), 203-213. Online: www.hadmernok.hu/171_16_jobbagy.pdf

Kőszegvári, Tibor, 'Hadviselés a 21. században'. Hadtudomány 9, no 1 (1999). Online: http://mhtt.eu/hadtudomany/1999/ht-1999-1-5.html

'MODUK - DEF STAN 23-012, Generic Soldier Architecture (GSA)'. Engineering 360, 14 May 2017. Online: https://standards.globalspec.com/std/10158433/defstan-23-012

Négyesi, Imre, 'COTS rendszerek alkalmazási lehetőségeinek vizsgálata'. Hadtudományi Szemle 4, no 4 (2011), 111-116. Online: https://epa.oszk.hu/02400/02463/00011/ pdf/EPA02463_hadtudomanyi_szemle_2011_4_111-116.pdf

Overview of Dismounted Soldier Systems. The NATO Science and Technology Organization, 2018. Online: https://apps.dtic.mil/sti/pdfs/AD1064371.pdf

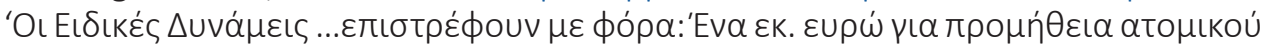

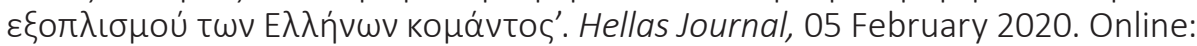
https://hellasjournal.com/2020/02/i-idikes-dinamis-epistrefoun-me-fora-enaek-evro-gia-promithia-atomikou-exoplismou-ton-ellinon-komantos/

'PIBS Comes to a Halt'. Soldier Modernisation, s. a. Online: www.soldiermod.com/ volume-6/pibs.html

'RIFS Acquires New C4I Suite'. Soldier Modernisation, s. a. Online: www.soldiermod. com/volume-4/romania.html

Rosen, Joseph L and Jason W Walsh, The Nett Warrior System: A Case Study for the Acquisition of Soldier Systems. Naval Postgraduate School, 2011. Online: https:// calhoun.nps.edu/handle/10945/10685

'Slovenia: Warrior of the $21^{\text {st }}$ Century'. Soldier Modernisation, s. a. Online: www. soldiermod.com/volume-2/slovenia.html

'Soldato Futuro Future Soldier System'. Army Technology, s. a. Online: www.armytechnology.com/projects/italiansoldiersystem/

'Soldato Futuro: 'Precursor' Systems Under Trial'. Soldier Modernisation, s. a. Online: www.soldiermod.com/volume-9/soldato-futuro.html

Szűcs, László, '„A Digitális Katona Program a Magyar Honvédség teljes gondolkodásmódját meg fogja változtatni”. Beszélgetés dr. Böröndi Gábor altábornaggyal, a Magyar Honvédség parancsnokának helyettesével'. Honvédelem.hu, 15 February 2021. Online: https://honvedelem.hu/hirek/a-digitalis-katona-program-a-magyarhonvedseg-teljes-gondolkodasmodjat-meg-fogja-valtoztatni.html

'TACP-Modernization'. Soldier Systems, s. a. Online: http://soldiersystems.net/2014/09/ 30/tacp-modernization/

'The Concise Global Industry Guide - C41 Systems'. C4I Systems Handbook no 12 (2018). Online: https://mags.shephardmedia.com/HB-samples-2018/C4IS12-webmag.pdf 
PÉTER TÖRÖK: A Brief Overview of Digital Military Systems Used in the Armies...

'Verbeterd Operationeel Soldaat Systeem'. Militaire-Uitrusting, s. a. Online: www. militaire-uitrusting.nl/onderwerpen/verbeterd-operationeel-soldaat-systeem Vergun, David, 'DOD Leaders Provide Digital Modernization Updates'. DOD News, 17 August 2020. Online: www.defense.gov/Explore/News/Article/Article/2315094/ dod-leaders-provide-digital-modernization-updates/

'Voják 21 looks to new weapons following trial reports'. Soldier Modernisation, June 2009. Online: www.soldiermod.com/volume-2-06/czech-v21.html

'Ways and Means'. Soldier Modernisation, s. a. Online: www.soldiermod.com/ volume-10/normans.html

'9Land Battle Management System'. Saab, s. a. Online: www.saab.com/products/9landbms 